\title{
AOR
}

Selected Papers of \#AolR2021:

The 22nd Annual Conference of the

Association of Internet Researchers

Virtual Event / 13-16 Oct 2021

\section{THE STREAMYARD CYPHERS: ONLINE PLACE-MAKING WITHIN AN INDIAN HIP HOP COMMUNITY}

\author{
Pradip K. Sarkar \\ School of Media \& Communications, College of Design \& Social Context, RMIT \\ University
}

\section{Introduction}

This paper presents an ethnographic account of how a community of Bengali-speaking rappers called the Cypher Projekt, based in the Indian state of West Bengal, created an online place for sociality during India's harsh Covid-19 lockdowns in 2020 (Jha and Mullick 2020). This attempt at online place-making is analyzed through Oldenberg's concept of the third place, and the Indian notion of informal sociality, or the adda (pronounced ud-dah).

\section{What is a Cypher?}

In Hip Hop culture, a rap "cypher" refers to an informal gathering of rappers. Akin to a poetry slam, a cypher is typically held in physical locations in which rappers engage in freestyle recitations for the purpose of entertainment, competition, and building rapport (Rose 2008, Porteous 2013, Kuttner and White-Hammond 2014). Cyphers are considered an integral aspect of Hip Hop culture and serve as rites of passage for aspiring rappers.

\section{Oldenberg's Third Place and the Adda}

The notion of the third place was introduced by the American urban sociologist Ray Oldenberg in his 1991 book entitled The Great Good Place, in which he described the third place as "a generic designation for a great variety of public places that host the regular, voluntary, informal, and happily anticipated gatherings of individuals beyond the realms of home and work." (1999, pp. 16). Oldenberg's third places centred around built spaces, such as neighbourhood taverns, pubs, and cafes, where informal sociality took place. He contended that for a third place to support civility and community building, it had to offer a neutral ground for informal hangouts that were perceived as egalitarian and unpretentious, and allowed people to engage in lively informal conversations. Such a notion of a third place bears conceptual similarities to the Indian social practice of the 
adda, which the social historian and postcolonial theorist, Dipesh Chakrabarty, described as "the practice of friends getting together for long, informal and unrigorous conversations", and provided "a comfort zone to cope with the ever changing forces of capitalist modernity" (2000, pp 181). Even though addas are a spatially dispersed social practice, different sites or locations shape the vibrancy and success of an adda session (Bhattacharya, 2017).These concepts provide the theoretical lenses through which the ethnographic study is analysed and discussed.

\section{The Ethnographic Study}

Based on online ethnographic research (Hine 2000, Postill and Pink 2012, Postill 2017), this paper draws upon a case study the Cypher Projekt, a grassroots initiative launched by a group experienced rappers in the city of Kolkata, but with memberships extending to young aspirants within the city as well as in the regional towns in West Bengal. The case study incorporates observations of the Cypher Projekt sessions held online during the Indian national lockdowns in 2020 , followed by interviews with individual members. The first online cypher was held in June, 2020, but owing to infrastructural challenges associated with Internet bandwidth and latency (Hammar and Marshall 2020), the cyphers were replaced with online discussion sessions that took place every Sunday. The sessions were livestreamed via the Cypher Projekt's Facebook page using Facebook Live and through their YouTube channel. However, the discussions were conducted using a freemium web-enabled video-conferencing application known as Streamyard, which is why the online sessions are referred to as the Streamyard cyphers. The first Streamyard session was held on Sunday, July 5, 2020, and the sessions continued thereon every Sunday till September 14, 2020. Whilst most the livestreamed sessions resembled informal discussion-style interviews, others involved panels in which several members participated. All the sessions were moderated by an emerging rapper who had volunteered for the role.

\section{Streamyard Cyphers as a Third Place}

The Streamyard cyphers bore many of the characteristics of Oldenberg's third place. The sessions consisted of informal conversations amongst participants that were lively and humorous. The conversations covered a range of issues from the rappers' musical practice to issues around language, politics, and gender, and general anxieties around Covid-19. Participants included members, both male and female, at various stages of their practice, from emerging rappers to experienced members with prominent profiles in the Kolkata music scene. Often extending over several hours, these sessions were wellattended as evident by the number of views and the liveliness of comments on Facebook. The sessions featured performances by participant rappers, often at the request of viewers through their comments.

The choice of digital technologies, namely the free version of the web-enabled Streamyard and popular platforms, such as Facebook, and YouTube, all of which could be accessed on mobile phones, ensured that the mostly millennial members of the Cypher Projekt were able to participate. Moreover, the simplicity of Streamyard's user interfaces and widespread familiarity with Facebook and YouTube aligned with the plain look-and-feel, or low profile, aspect of third places. Ofcourse, the Streamyard cyphers, 
unlike the physical cyphers, were not really cyphers in terms of the performed competitiveness that is an essential practice in Hip Hop cultures. This lack of competitiveness also accounted for the relaxed informality of the online hangouts. The Streamyard cyphers more closely resembled a third place than the physical cyphers.

\section{Rethinking Oldenberg's Third Place}

However, a re-thinking of Oldenberg's concept necessitates a consideration of the fact that social hierarchies are not always flattened or leveled in a third place. Observations of interactions amongst the participants in the Streamyard sessions revealed a reverence for members with greater cultural capital (Bourdieu and Johnson 1993) as well as seniority. Soukup (2006) and Steinkuehler and Williams (2006) have also indicated the presence of social hierarchy in their application of the concept to studies of online sociality. Moreover, the emphasis on Bengali vocalisation in rap excluded many nonBengali rappers that often attended the physical cyphers. Oldenberg's description of the neutrality of third places also comes into contestation as the more active participants in the Streamyard cyphers were part of an in-group of Bengali rappers that had often collaborated and performed with each other. Members that were not part of the this ingroup kept a lower profile.

The focus on white middle-class (and male) suburban America as the sociocultural contexts around which third places manifest (Soukup 2006, Fullagar, O'Brien et al. 2019) also problematises the application of Oldenberg's concept in the context of a Global South nation, such as India. This is where scholarly discourses around the Indian social practice of the adda can offer nuanced perspectives into the application of Oldenberg's third place, owing to its ability to incorporate aspects of social hierarchy and cliquishness in informal sociality (Bhattacharya 2017). The homeliness of a third place also calls for a rethink at a time of Covid-induced lockdowns, as members of the Cypher Projekt sought online sociality "to escape this sense of confinement and isolation" within their homes (Watson, Lupton et al. 2021, pp. 147). This adds to the arguments against Oldenberg's skepticism around online environments as third places (Soukup 2006, Steinkuehler and Williams 2006, McArthur and White 2016). The Streamyard cyphers clearly offered a vibrant third place for the undertaking of addas by the members of the grassroots Hip Hop community amid the Covid-induced Indian lockdowns of 2020. While Oldenburg's notion of the third place holds relevance for the examination of informal sociality, including online sociality, in the Global South, its application requires augmentation with scholarly analyses of social practices in specific sociocultural contexts. 


\section{References}

Bhattacharya, B. (2017). Adda and Public Spaces of Sociability before the ICH. Much Ado Over Coffee, UK, Routledge: 23-82.

Bourdieu, P. and R. Johnson (1993). The Field of Cultural Production: Essays on Art and Literature, USA, Columbia University Press.

Chakrabarty, D. (2000). Provincializing Europe: Post-Colonial Thought and Difference. Princeton, Princeton University Press.

Fullagar, S., et al. (2019). Rethinking Third Places. Feminist perspectives on third places, UK, Edward Elgar Publishing.

Hammar, N. and C. Marshall (2020). "Playing Music Together Online Is Not As Simple As It Seems." NPR. Retrieved April 10, 2021, from https://www.npr.org/2020/07/14/891091995/playing-music-together-online-is-notas-simple-as-it-seems

Hine, C. (2000). Virtual Ethnography. London, Sage.

Jha, A. and J. Mullick (2020). How the world's strictest lockdown affected India. Hindusthan Times. New Delhi. Retrieved January 12, 2021, from https://www.hindustantimes.com/india-news/how-the-world-s-strictest-lockdownaffected-india/story-hi960xJcyZe53JHb5f6gwN.html

Kuttner, P. J. and M. White-Hammond1 (2014). (Re)building the cypher Fulfilling the promise of hip hop for liberation. The Organic Globalizer: Hip Hop, Political Development, and Movement Culture. C. Malone and G. M. Jr., USA, Bloomsbury Academic \& Professional: 43-57.

McArthur, J. A. and A. F. White (2016). "Twitter Chats as Third Places: Conceptualizing a Digital Gathering Site." Social Media + Society 2(3): 2056305116665857.

Oldenburg, R. (1999). The Great Good Place: Cafes, Coffee Shops, Community Centers, Beauty Parlors, General Stores, Bars, Hangouts and How They Get You Through the Day. New York, USA, Marlowe \& Company.

Porteous, C. (2013). Rap's collective consciousness: the significance and dynamics of cypher in hip hop culture, PhD thesis, Newcastle University, UK.

Postill, J. (2017). Remote Ethnography: Studying Culture from Afar. The Routledge Companion to Digital Ethnography. L. H. Hjorth, H.; Galloway, A.; Bell, G., UK, Taylor \& Francis: 61-69.

Postill, J. and S. Pink (2012). "Social Media Ethnography: The Digital Researcher in a Messy Web." Media International Australia, Incorporating Culture \& Policy (145): 123-134. 
Rose, T. (2008). The hip hop wars: What we talk about when we talk about hip hop--and why it matters, USA, Civitas Books.

Soukup, C. (2006). "Computer-mediated communication as a virtual third place: Building Oldenburg's great good places on the World Wide Web." New Media \& Society 8(3): 421-440.

Steinkuehler, C. A. and D. Williams (2006). "Where everybody knows your (screen) name: Online games as "third places"." Journal of computer-mediated communication 11: 885-909.

Watson, A., et al. (2021). "Enacting intimacy and sociality at a distance in the COVID-19 crisis: the sociomaterialities of home-based communication technologies." Media International Australia 178(1): 136-150. 